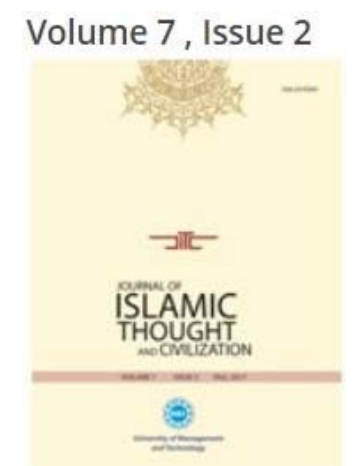

Journal of Islamic Thought and Civilization (JITC)

Volume 7, Issue 2, Fall 2017

ISSN: 2075-0943, EISSN: 2520-0313

Journal DOI: https://doi.org/10.29145/jitc

Issue DOI: https://doi.org/10.29145/jitc/72

Homepage: https://www.umt.edu.pk/jitc/home.aspx

Journal QR Code:
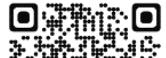

\section{Article:}

Author(s):

Online Published:

Article DOI:

Article QR Code:
Ombudsman (Muhtasib) in Business Regulation: A Cross Cultural Analysis

Sodiq Omoola Olalekan

Nurah Sabahiah Mohamed

October 2017

doi.org/10.29145/2017/jitc/72/070202

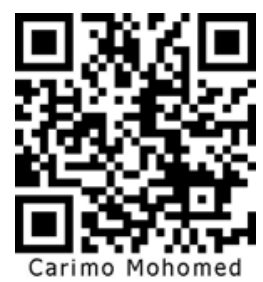

Olalekan, Sodiq Omoola, and Nurah Sabahiah Mohamed. "Ombudsman (Muhtasib) in business regulation: A cross cultural analysis.” Journal of Islamic Thought and Civilization 7, no. 2 (2017): 18-40. DOI: https://doi.org/10.29145/2017/jitc/72/070202

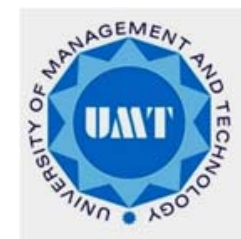

A publication of the

Department of Islamic Thought and Civilization

School of Social Science and Humanities

University of Management and Technology

Lahore 


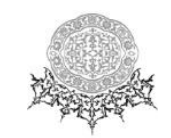

\title{
Ombudsman (Muhtasib) in Business Regulation: A Cross Cultural Analysis
}

\section{Sodiq Omoola Olalekan}

Ahmad Ibrahim Kulliyyah of Laws,

International Islamic University Malaysia, Malaysia

Nurah Sabahiah Mohamed

Ahmad Ibrahim Kulliyyah of Laws, International Islamic University Malaysia, Gombak Campus, Malaysia

\begin{abstract}
Ombudsman, known as Muhtasib in Islamic tradition; is an independent, impartial, and confidential complaint handler who serves as an alternative means of dispute resolution. Historical account shows that ombudsman institutions have been known in different cultures with various nomenclatures. The Islamic Muhtasib which has been proven to predate its similitude in other cultures is an evidence of cross-cultural learning from Islamic tradition to other cultures. This remains factual notwithstanding the lack of homogeneity of its origin as well as its modern usage in public administration, human right and business regulation. Through the use of doctrinal approach and library tools, the paper presents histology of ombudsman in the Islamic, Greek, Chinese and Scandinavian tradition. The study finds that ombudsman in the Islamic legal tradition is more suitable to business regulation than similar institution which exists in other cultures.
\end{abstract}

Keywords: Muhtasib, agoranomos, business regulation, Islamic tradition

\section{Introduction}

The ombudsman concept has grown from being a medieval administrative mechanism into a modern tool for market regulation, complaint handling, consumer protection and access to justice. ${ }^{1}$ The precursor of existing ombudsman practice can be traced to the Scandinavia while similar institutions also existed in Indian, Chinese and Muslim legal traditions. This paper under takes a cross-cultural analysis of ombudsman, evolution and formative stage in the Islamic era, Greek civilization, Chinese and the Scandinavia before its eventual spread to the Americas, the Pacific, Africa and other parts of the world.

Historically, ombudsman has been used in several contexts in different legal cultures, whether as an institution, a natural person holding an office or as one of the array of Alternative Dispute Resolution (ADR) mechanisms. ${ }^{2}$ This paper attempts to

${ }^{1}$ Donald C. Rowat, “The New Private-Sector Ombudsmen," Policy Options 24, no. 10 (2003): 46-48.

${ }^{2}$ Shirley A. Wiegand, “A Just and Lasting Peace: Supplanting Mediation with the Ombuds Model," Ohio St. J. on Disp. Resol 12 (1996): 95. 


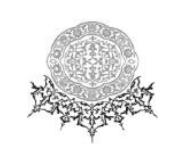

examine the meaning and conceptual understanding of ombudsman, its origin and cultural underpinnings in legal traditions including Islamic law. In addition, modern trends in ombudsman classification are also discussed in specific public sectors such as hospital, long-term care, employment, army, police, etc. ${ }^{3}$ Private sector ombudsman has been developed in banking, insurance, construction, newspaper/press and other private enterprise. This is not unconnected with the transfer of government to private entities. ${ }^{4}$

The paper begins with attempts to provide acceptable definition, followed by a cross cultural analysis in historical terms with an emphasis on Muhtasib. Modern classification and the relevance of ombudsman in business regulation are also discussed.

\section{Contemporary Definitions of Ombudsman}

Modern Ombudsman has been attributed to the Scandinavia to mean any kind of person or office persons responsible for monitoring government administration, and known in Swedish language as 'justiteombudsman' or chancellor of justice. ${ }^{5}$

Since the emergence of classical ombudsman, several definitions have been advanced by Ombudsman bodies, association, and researchers. The definitions have reflected the characters of the various institutions and jurisdictions which have shown interest in the growth and development of ombudsman scheme around the world. It is argued that there is some kind of obscurity about the Islamic origins of Ombudsman in Western literature. ${ }^{6}$ This section will examine the attempts to define the term from the understandings and opinions in the ombudsman literature.

One of the earliest definitions of the term was presented in the 1974 resolution of the International Bar Association (IBA) Ombudsman Committee, which reads as follows:

An office provided for by the constitution or by action of the legislature or parliament and headed by an independent, high-level public official who is responsible to the legislature or parliament, who receives complaints from aggrieved persons against government agencies, officials, and employees or who acts on his own motion, and who has the power to investigate, recommend corrective action, and issue reports. ${ }^{7}$

\footnotetext{
${ }^{3}$ Linda C. Reif, The International Ombudsman Anthology: Selected Writings from the International Ombudsman Institute (Martinus Nijhoff Publishers, 1999), 52.

${ }^{4}$ Rhoda James, Private Ombudsmen and Public Law (Ashgate, Dartmouth, 1997).

${ }^{5}$ Reif, The International Ombudsman Anthology: Selected Writings from the International Ombudsman Institute, 52.

${ }^{6}$ Sara Thacker, "Good Intentions Gone Astray: How the ABA Standards Affect Ombudsmen," Journal of the International Ombudsman Association 2, no. 1 (2009): 65.

7 “Ombudsman Committee, International Bar Association Resolution” (Vancouver: International Bar Association, 1974).
} 


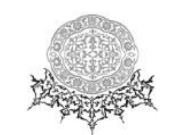

This definition gained the acceptance among legal circles as a form of nonjudicial complaint handling mechanisms which can be used by legal institutions around the world. ${ }^{8}$ The basis for the definition was borne out of series of consultation by the International Commission of Jurist (ICJ) which were held at the 1965 Bangkok South-East Asian and Pacific, 1966 Colombo Colloquium on Rule of Law and the 1968 Conference on the Individual and the State. ${ }^{9}$ A critical analysis of the above definition shows that ombudsman must be premised upon the constitution or 'action of the legislature.' In addition, complaints that will be submitted must be against public officials, employees or agencies only. In other words, private persons, corporations and other non-governmental entities are excluded. This definition still envisages an era where complaints against private bodies should be handled by the court of law and ombudsman be confined to public maladministration only. In other words, it will be unnecessary to have ombudsman in the context of business or market regulation.

Larry B. Hill views ombudsman as an officer with the mission "to generate complaints against government administration, to use its extensive powers of investigation in performing a post-decision administrative audit, to form judgement which criticize or vindicate administrators, and to report publicly its finding and recommendations but not to change administrative decisions." 10 This definition tries to capture the proactive ombudsman who uses his investigative power instead of waiting for complainants.

Simplification in defining ombudsman was initiated as a result of the growing interest of professional bodies in the use and promotion of Alternative Dispute Resolution (ADR). Few institutions with special interest in Ombudsman include: The American Bar Association (ABA), The Ombudsman Association (TOA) and University and College Ombuds Association (UCOA). The Standard of Practice issued by the TOA describes the Ombudsman's mission as "to provide a confidential, neutral and informal process which facilitates fair and equitable resolutions to concerns that arise in the organization."11 This definition appears to be the first attempt to incorporate both public and private organizations, a phenomenal departure from public-centric contexts. It also tries to capture the main features of an ombudsman without being normative or judgemental, thus reflecting the growing number of private Ombuds practice in the United States during this period.

\footnotetext{
${ }^{8}$ Bernard Frank, “The Ombudsman-Revisited,” International Bar Journal 6 (1975): 49.

${ }^{9}$ Ibid., 50.

${ }^{10}$ Larry B. Hill, "The Institutionalization, the Ombudsman, and Bureaucracy," American Political Science Review 68, no. 3 (1974): 1077.

11"The Ombudsman Association - Standards of Practice," Accessed March 16, 2016, $<$ http://web.mit.edu/negotiation/toa/TOAsop.html $>$.
} 


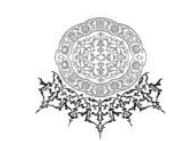

In an attempt to make a position on the advancement of Ombuds practice in the United States, the American Bar Association (ABA) Ombuds committee adopted series of resolutions in 1969, 1971, 2001 and 2004. In 2004, the house of delegate an organ of the ABA in its Standard for the Establishment and Operation of Ombuds Office defined Ombudsman as follows, "An independent, impartial, and confidential complaint handler" who "serves as an alternative means of dispute resolution-a means by which issues may be raised, considered, and resolved."12

This definition seems to cover the field as it does not restrict the context of Ombuds practice to either private or public sector. In addition, the inclusion of ombudsman as one of the array of ADR mechanisms available has been firmly established as well through the ABA resolution.

From the foregoing, there are various orientations and thoughts in defining or explaining the role of ombudsman vis-à-vis: person who receives complaint against public officials, a non-judicial complaint handling mechanism, a means of dispute resolution and an internal mechanism for complaint handling in an organization (private ombuds). This perceived lack of uniformity ${ }^{13}$ in the understanding of ombudsman has contributed to its flexibility and adaptability to various public and private sector access to justice and complaint handling. Based on the varying roles played by ombudsmen and the lack of uniformity in their standard and characteristics, the argument for and against an acceptable definition continues till date.

\subsection{Ombudsman as ADR Institution}

Despite the divergent development of the intertwined concept of ADR and Ombudsman, both have become synonymous in form and practice. Ombudsman has grown to be recognised as a part of the ADR system and techniques. In the field of Alternative Dispute Resolution (ADR), it could be difficult to distinguish Ombudsman either as an institution or mechanism.

Discussions on ADR in academic literature ${ }^{14}$ have considered ombudsman distinctively as one of the several mechanisms of ADR alongside mediation,

\footnotetext{
12“Standards for the Establishment and Operation of Ombuds Offices 2001," American Bar Association, accessed April 14, 2016, http://www.americanbar.org/content/dam/aba/migrated/2011_build/dispute_resolution/attach.authchec kdam.pdf.

${ }^{13}$ Thacker, "Good Intentions Gone Astray: How the ABA Standards Affect Ombudsmen," 82.

${ }^{14}$ Richard Chernick, "ADR' Comes of Age: What Can We Expect in the Future?" Pepperdine Dispute Resolution Law Journal 4, no. 2 (2012); Jean R Sternlight, "Is Binding Arbitration a Form of ADR ?: An Argument That the Term 'ADR' Has Begun to Outlive its Usefulness," 1 (2013); Justice J. N. Bhatt, “Ombudsman: An Effective ADR,” All India Reporter 88
} 


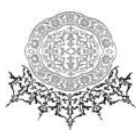

conciliation, arbitration. On the other hand, ADR legislations have positioned Ombudsman institutions as the main platform for the use of all ADR mechanism in the resolution of complaint and disputes. In other words, Ombudsman institution on the weight of its establishment clause may be permitted to conduct mediation, reconciliation, arbitration or any ADR process.

Academic discourse may compel a distinction of Ombudsman and ADR. One of the distinction can be found in the fact that virtually all ADR processes could be court annexed, that is initiated as a part of court proceeding and may be unconnected with Ombudsman institution. On the other hand, ombudsman seldom has any form of reference to the court. On the contrary, in some cases a dissatisfied citizen can proceed to the court after the decision of an ombudsman.

It is not clear that at which point ADR absorbed Ombudsman which are of American and Swedish systems, respectively. The fusion of these systems has however become spectacular in the administration of justice and public service delivery around the world. Despite this fusion, cost and accessibility have continued to be a major edge for ombudsman services compared to other redress mechanisms.

Globally, the person serving in the ombuds office is historically known as an 'ombudsman' in plural 'ombudsman' irrespective of the gender of the person incharge. There have been attempts by feminist legal academics to find a gender neutral nomenclature while accusing it as a gender biased word. ${ }^{15}$ This was seen as undermining the effectiveness of workplace ombudsman and organisational ombudsman towards women. Hence, gender-neutral such as ombudet, ${ }^{16}$ 'ombudsperson' or 'ombuds practitioner' 17 have been suggested as an alternative. Perhaps a feminist twist to a noble concept, it has been as strong as to cause a name change through an amendment of the Ombudsman Act to read 'Ombudsperson Act' in British Columbia (BC). ${ }^{18}$ It has also gain usage in literatures in some parts of the world. ${ }^{19}$

(2001): 1049; Joon Shin, Legal Studies, and Honors Thesis, "Discussion on the Models of ADR," (2011): 1-29.

15"Gendered Language: An Ombudsman by Any Other Name Would Still Field Complaints,"

The Economist, accessed March 1, 2016,

http://www.economist.com/blogs/johnson/2013/04/gendered-language.

${ }^{16}$ Norwegian term for ombudsman is deemed to be gender neutral.

${ }^{17}$ Wiegand, "A Just and Lasting Peace: Supplanting Mediation with the Ombuds Model," 96.

18“OMBUDSMAN ACT [Retitled as Ombudsperson Act] [RSBC 1996] CHAPTER 340,"

accessed March 1, 2016, http://www.bclaws.ca/civix/document/id/consol21/consol21/e2tlc96340a; Tim Griffin, "The Evolution of the Role of Ombudsperson on University and College Campuses," The Fourth R (the Newsletter of the National Association for Mediation in Education) 55 (1995).

${ }^{19}$ Florian Hoffmann and Frédéric Mégret, "Fostering Human Rights Accountability: An Ombudsperson for the United Nations?," Global Governance: A Review of Multilateralism and International Organizations 11, no. 1 (2005): 43-63; Grant L. Willis, "Security Council Targeted 


\section{상}

The use of Ombudsman as a redress and complaint mechanism in both the public and private sectors has increased in the last few decades. ${ }^{20}$ The classification of ombudsman has become a growing aspect of ombudsman research due to the increasing adaptation for several sectors including prison, health care, insurance, banking, university, legal services, workplace, press, employment among others.

From the early classical ombudsman in Sweden, the public sector thrived in the deployment of Ombudsman to ensure accountability, effectiveness and prevent public maladministration. All public institutions are creation of constitutions and legislations; thuspublic ombudsman offices must be backed by law. Therefore, parliamentary, legislative and all forms of public service and civil service duties fall under the purview of public sector ombudsman. ${ }^{21}$

Similarly, private-sector ombudsman has thrived on the need to avoid litigation, adversarial process and ensure confidentiality in handling complaint by customers or consumers. Aside the cost of litigation, court cases with a consumer tend to give bad publicity and increased reputational risk to corporate entities, hence everything must be done to avoid it. The explosion of ombudsmen schemes has made industry self-regulation a field of special interest in commercial and business environments. ${ }^{22}$ One seems to argue against the use of the term 'ombudsman' to refer to internal complaint handling system of private of corporate entities. It has been argued that the use of the name 'ombudsman' to refer to internal redress mechanism could be misleading to the public rather than protecting them. ${ }^{23}$ Current realities in dispute resolution and redress mechanisms have revealed that the term cannot be exclusively applied to the public sector only.

\section{Ombudsman: A Cross Cultural Analysis}

Historically, ancient cultures and societies like the Romans, Egyptians, the Chinese Han Dynasty, Indian and the Ottoman had some sort of citizen complaint mechanism in their public administration and court systems which were known by different names and forms. ${ }^{24}$ This section will examine traceable features of

Sanctions, Due Process and the 1267 Ombudsperson," Geo. J. Int'l L. 42 (2010): 673; Brian Gran and Dawn Aliberti, "The Office of the Children's Ombudsperson: Children's Rights and Social-Policy Innovation," International Journal of the Sociology of Law 31, no. 2 (2003): 89-106; H. Gadlin and E. Pino, "Neutrality: What an Organizational Ombudsperson Might Want to Know," Dallas: The Ombudsman Association, 1997.

${ }^{20}$ Rowat, "The New Private-Sector Ombudsmen," 47.

${ }^{21}$ James, Private Ombudsmen and Public Law.

${ }^{22}$ Ibid., 262.

${ }^{23}$ John McMillan, "What's in a Name? Use of the Term 'Ombudsman,"” Presentation, Commonwealth Ombudsman to the Australian and New Zealand Ombudsman Association (2008): 1.

${ }^{24}$ Gerald E. Caiden, Niall MacDermot, and Ake Sandler, The Institution of Ombudsman, International Handbook of the Ombudsman: Evolution and Present Function, vol. 1 (Westport, CT: Greenwood Press, 1983). 


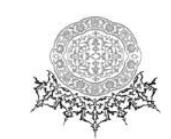

ombudsman in ancient legal traditions and consider the influence of the Scandinavian ombudsman as a successful legal consensus around the world.

\subsection{Ombudsman in Islamic Legal Tradition}

This section examines the development of Muhtasib, hisbah and its use as a market regulatory tool in the early Islamic Era which serves the basis of ombudsman in western civilization. The influence of Islamic legal tradition in the development of Ombudsman concept in Western societies is rarely acknowledged. Literally known as Muhtasib and derived from the word Hisbah or accountability. The Turkish institution of Qadhi'ul'Qudhät which attracted the attention of King Charles is however a practice recorded in Muslim tradition where the Prophet Muhammad $(S A W)$ will sit in the mosque to hear grievances from the public as an example which was passed down to the Caliphs ${ }^{25}$ and the subsequent Ottoman institution known as Qadhi'ul'Qudhāt. ${ }^{26}$

In the early Islamic era, the quest for public and administrative institution for grievance appraisal and redress was necessitated by the annual influx of pilgrims from around the world. The spread of Islam in Persia, Andalusia and other part of Europe including Turkey further made the Muhtasib an essential part of public life in Muslim societies.

Within the context of business regulation in the Islamic era, it was on record that Muhatsib was essential to regulating commerce in market places around Arabia. The need to regulate the $s \bar{u} q$ or markets in Makkah and Medina and other commercial activities which was a necessary and non-ritual part of the pilgrimage also assisted to build the commercial use of the term Muhtasib who were known as Amil 'ala sūq. ${ }^{27}$ Buckley asserts that there was no record of an official Muhtasib during the jahiliyah period, therefore it seems to be a product of Islam and the spectacular leadership qualities of Prophet Muhammad $(S A W)$. Ibn Hazm recorded that there were personalities such as Hakim bin Umayya who was a hakim (arbitrator) and known for 'ordering good and forbidding evil' during the jahiliyah. ${ }^{28}$ Where an arbitrator could not resolve the dispute or proved ineffectual, further appeal was made to the kahin (soothsayer) who was believed to possess divine

\footnotetext{
${ }^{25}$ Pedro Vernia, "The Muhtasib of Valencia and Pharmacy in Aragon," Pharmacy in History 30, no. 2 (1988): 89-93; Benjamin R. Foster, "Agoranomos and Muhtasib," Journal of the Economic and Social History of the Orient/Journal de L'histoire Economique et Sociale de l'Orient (1970): $128-44$.

${ }^{26}$ Ziaullah Rahmani, "Wafaqi Mohtasib (Federal Ombudsman) Institution: An Effort of Harmonization with Shari 'ah,” Annual Report of the Wafaqi Mohtasib, (1985): 5-6.

${ }^{27}$ R. P. Buckley, “The Muhtasib,” Arabica 39 (1992): 59-117.

${ }^{28}$ Ibn Hazm and Abu Muhammad'Ali, “Jamharat Ansāb al-'Arab, Edited, Abd Al-Salām Hārūn (Cairo, 1962), 400.
} 


\section{-}

inspiration and was most likely to provide positive and acceptable results for the disputants. $^{29}$

The Qur'ān strengthens the legal basis for market and business regulation through prescriptions in Surah Mutaffifin, which is concerned with wrongful and fraudulent practices in the market. The term 'Mutaffifin' literally means 'dealer in fraud' and it was further elucidated by at-Tabari to mean a person who gives deficient weight and measures or perpetrates insufficiency in calculation and quantity. The opening verses of the chapter in the Qur'ān were as follows, "Woe to those who deal in fraud. Those who, when they have to receive by measure from men, exact full measure. But, when they have to give by measure or weight to men, give less than due." 30

The prescription in the Qur'ān has made it more of interest to Arabs and Muslims to study physical components and substances of materials for the purposes of ascertaining the weight. ${ }^{31}$ Anton opined that the study of science and arts related to weights and measures in the Muslim world exceeds the attention given to it by the Greeks.

In line with the Islamic injunction "to give full measure and to weight with the right scales" 32 several terms and metric systems have been used to refer to different commercial and non-commercial objects and subjects. Such objects and subjects include: length, capacity, area weight, currency, cloth, grains, livestock, human capacity, meteorological measurements, and weather among others. ${ }^{33}$ Depending on the geographical location, politics, law and diverse culture within the Muslim world various metric systems were developed in order to regulate market practices and avoid conflict in business dealings. From the Qur'ān and Hadiths, Ulrich identified about 66 terms in the Islamic metric systems which were developed within the geographical units of the Islamic world i.e., the Arab West, from Andalusia to Iraq and Persia to India. ${ }^{34}$ Some of the units of scale which are still relevant today include: dinār, dirham, mudd for grains, kirāt for gold, etc. It must be noted that all the scales have some legal and political authority within its jurisdiction and also strengthen by the resolve of Muslims to ensure compliance within the market.

\footnotetext{
${ }^{29}$ Buckley, "The Muhtasib," 61.

${ }^{30}$ Qur'ān: Mutaffifìn 83:1-3.

${ }^{31}$ Anton M. Heinen, "At the Roots of the Medieval Science of Weights. A Report on an Edition Project," Journal of Sophia Asian Studies 1 (1983): 44-55.

${ }^{32}$ Qur'ān: Isra 17:35.

${ }^{33}$ Ulrich Rebstock, "Weights and Measures in Islam," in Encyclopaedia of the History of
} Science, Technology, and Medicine in Non-Westen Cultures, ed. Helaine Selin (Netherland: Springer Science and Business Media, 2008), 2256.

${ }^{34}$ Ibid., 2257. 


\section{상}

There were certain criteria for appointment as the Muhtasib during this period in addition to the requirement that such person must be known by the community, trade or profession. Classical Muslim exegetists such as Ibn Khaldūn and Yahya alAndalūsi consider the qualification of a Muhtasib as similar or the same as that of the Qadi due to the public judicial role they perform. ${ }^{35}$ However, al-Mawardi specifically mentions that such person should be a freeman, uncompromising, stern and judicious with 'knowledge of objectionable actions. ${ }^{36}$ Similarly, it is not clear whether appointees must be retired Qadi or fuqaha although there are evidence of such person being appointed. The similarity between the qualifications of Qadi (Judges), Shurta (Police) and Hisba or Muhtasib has been attributed to the institutional diffusion which is very apparent in some part of the Muslim world due to the similarity of purpose and religious nature of these offices. This reached the extent that one person is granted or appointed as the Muhtasib and Shurta at the same time. ${ }^{37}$

In the analysis of classical Islamic text titled Kitab al-Nazar wa al-ahkam fi Jami Ahwal al-Suq (Book on Supervision and legal decision on matters related to the market) Ahmad and Normah ${ }^{38}$ discussed some fraudulent business practices and how they were addressed. In order to avoid arbitrariness while allowing some level of discretion several Hisba Manuals were written as a guide for regulators in determining punitive and remedial measures for stakeholders in the market. There are two fundamental duties of the häkim (arbitrator), Amil 'ala süq or market officers $v i s-a$-vis ensure orderliness in the running of the market and to dispense justice according to the Shari 'ah in case of any infringement or disagreement.

It is apparent that the market regulator or hisbah does not necessarily adopt a 'wait and see' approach in the performance of his activities. In other words, he is more proactive in detecting wrongful conduct. This proactiveness is a major distinguishing factor between the häkim (arbitrator) and the Qadi (Judge). ${ }^{39}$ Thus, the powers exercised by the Muhtasib can be considered as a necessary form of economic intervention to avoid commercial and social anarchy.

With respect to the enforcement powers of market regulators by the Amil 'ala suq, Muhtasib or Hakimi, Yahya ibn Umar opined that the officer can order for return of defective products or goods order the vendor, payment of compensation,

${ }^{35}$ Muhammad Al-Mawardi, Al-Ahkām al-Sultaniyyah (Cairo: Al Halabi Press, 1960), 208.

${ }^{36} \mathrm{Ibid}$.

${ }^{37}$ Buckley, "The Muhtasib," 81.

${ }^{38} \mathrm{Ahmad}$ Che Yaacob and Normah Omar, "Fraudulent Business Practices in Early Islam as Reported in a Classical Text," Malaysian Accounting Review 13, no. 1 (2014): 129-42.

${ }^{39}$ Karen Kern et al., Dispensing Justice in Islam: Qadis and their Judgments (Leiden: Brill, 2010). 


\section{-}

destruction or confiscation of unlawful goods, whipping with lashes, ban from the market, among others. ${ }^{40}$

The practice of Muhtasib has been highly synonymous with market regulation although there are evidences of its use in other forms of specialized trade and its diffusion in other mundane aspects of daily living. The Muhtasib was also appointed to ensure proper regulation of day-to-day activities beyond market setting into other commercial and non-commercial endeavours. It is known in ancient records and classical writings that Muhtasib were active in the development and regulation of pharmacy, shipping, animal husbandry, leather works, medicine, teaching, public facilities among others. ${ }^{41}$

It has been noted that scholars in the field of Ombudsman histology have given conflicting accounts on the origin of modern day ombudsman. Between the Greek Agoranomos and Islamic Muhtasib, it is not clear which one has dominance in ombuds mechanism in public administration. Buckley ${ }^{42}$ and Foster ${ }^{43}$ are among the foremost scholars who have argued that definitely Muhtasib precedes Agoranomos while Glick ${ }^{44}$ proffers an alternative argument which supported institutional diffusion. The next section will examine the Greek Agoranomos and its influence in the growth of modern ombudsman concept.

The spread of the Islamic empire to Andalusia had ensured the transplantation of the Muhtasib to Spain under the name almotacen which regulates public and morality in accordance with Islamic injunctions. Although modern Ombudsman literature have not given adequate credits to the concept and practice of Muhtasib as given to the Agoranomos.

\subsection{The Greek/Roman Agoranomos}

The second ancient origin attributable to modern ombudsman after the Muhtasib is the Agoranomos of the Greek/Roman civilization. In the ancient Greek tradition, the word Agoranomos which literally means 'market inspector' was an official who has the duty of inspecting the market. ${ }^{45}$ Due to its importance, the office

\footnotetext{
${ }^{40}$ Yaacob and Normah Omar, "Fraudulent Business Practices in Early Islam as Reported in a Classical Text," 138.

${ }^{41}$ Abu Saim Md. Shahabuddin, "Regulation of Economic Life in Hisbah Literature," (International Islamic University Malaysia, 2009), 278-339.

${ }^{42}$ Buckley, "The Muhtasib."

${ }^{43}$ Foster, "Agoranomos and Muhtasib."

${ }^{44}$ Thomas F. Glick, “'Muhtasib' and 'Mustasaf': A Case Study of Institutional Diffusion,” Viator 2 (1971): 59.

${ }^{45}$ Foster, "Agoranomos and Muhtasib"; M. G. Raschke, "The Office of Agoranomos in Ptolemaic and Roman Egypt," Akten Des 13. Internationalen Papyrologenkongresses (1974): 349-56; Daniel Sperber, "On the Office of the Agoranomos in Roman Palestine," Zeitschrift Der Deutschen Morgenländischen Gesellschaft 127, no. 2 (1977): 227-43.
} 


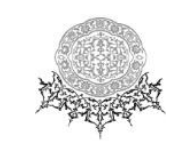

remained in the minds of the people even after the Roman conquest of the Greek with some inscription public places. ${ }^{46}$ The system also spread to parts of Asia Minor, Egypt and Palestine during the Roman reign. ${ }^{47}$ However, the function became expanded beyond market officer to maintenance of public places. According to Benjamin, who cited the works of the Plato, the duties and function of the Agoranomos was mainly to enforce the decision of the ruler with the help of retailers. He stated succinctly as follows:

The agonaromos would find out from experienced retailers all the adulterations and trickery practices by unscrupulous merchants and would post them too as a sort of buyers' guide. He was to watch over the temple in the agora lest any offense be perpetrated therein. He should wander through the markets with a whip in his hand to administer summary punishment to offenders if they were not citizens. If they were citizens, they were to be mulcted according to the law. If the charge was denied the agonaromos would administer an oath, for it was considered unlikely that a man would risk the wrath of the gods to save a fine. His colleague the astynomos was responsible for the maintenance of the streets and public buildings outside the agora; the Agoranomos was responsible for the inside. ${ }^{48}$

The role of the Agoranomos and the Muhtasib in the Islamic traditions are both proactive in their duties. Although the name Agoranomos became out of use in the third century, it was referred to as aedile. Benjamin argued that the name or title of a man who perform the function of ombudsman in the Roman and Byzantine Empire was not as important as the function and powers of the official. Thus an aspect of the Digests of Justinian urban law shows the office of someone who oversees road maintenance, water, grain supply, policing etc.

In distinction with the Muhtasib, the Agoranomos or aedile performs some public benefactor role which includes: repair of public baths and temples, supply furniture to market restaurants or hall, provide oil for the public gymnasia for nonfinancial reward such as memorial, public wreath or honour initiation into high societal status. ${ }^{49}$ It is however uncertain whether there is any basis for comparison on the basis of date and occurrence in the context of ombudsman research.

\subsection{Ombudsman in Chinese Legal Tradition}

The Chinese civilization and its public control system is also important in the array of ancient Ombuds practice around the world. This is because the Chinese legal tradition possesses semblances of ombudsman which have been observed to be older than the Danish Parliamentary Ombudsman Act of 1954. According to Pai ${ }^{50}$ Chinese Control system known as the Control Yuan dates back to 221 B.C. and was

\footnotetext{
${ }^{46}$ David Magie, Roman Rule in Asia Minor, vol. 6 (Princeton, 1950), 1511.

${ }^{47}$ Ibid.

${ }^{48}$ Foster, "Agoranomos and Muhtasib."

${ }^{49}$ August Boeckh, Corpus Inscriptionum Graecarum, vol. 1 (Berlin: Reimer, 1843), 1125.

${ }^{50}$ Pai-Chuan Tao, "The Chinese Ombudsman and Control System," St. John's Law. Review, 41 (1966): 362.
} 


\section{.}

reaffirmed in the 1947 Chinese Constitution. This predates the American and British ombudsman which emerged in the 1960s.

The Control Yuan with over one hundred and eighty members was seen as formidable and significant. It was considered as a branch of the parliament with representation in the municipal and provincial councils as far as former Chinese provinces in Vietnam, Mongolia and Tibet. ${ }^{51}$ The office of Imperial Censor-General also known as $\mathrm{Yu}$-shih ta-fu which is the head of control Yuan was established as a measures taken by the Emperor Shi Huang of the Qin Dynasty (221 to 206 BC) to protect his kingdom. Just as the Great Wall served as a defence line the censorate was meant to prevent public officials from neglecting their duties. ${ }^{52}$ The censorate exercises powers over consent on impeachment, auditing, correction among others. Increased recognition was granted to the office censorate and assigned with the privileges of the Prime Minister and can exercise impeachment process on the Prime Minister or any office whatsoever.

During the Ching dynasty of 1637, the Emperor had established a court known as the Censorate to monitor breaches by public officials including the Emperor, princes and his appointees. The duty of the Censorate court was captured in the words of the Emperor as follows:

The Censors are to criticize straightforwardly my extravagance, mistreatment of the loyal and the able, being indulged in hunting, negligence of duty, demotion of meritorious, appointment of the unfit, or promotion of the unserviceable. If the princes neglect their work, take property from the people without due compensation, or indulge in wine, women, or any sensual pleasure, the Censorate shall investigate and impeach them. If the six departments or their ministries decide things wrongly, or delay review or trial of criminal cases, the Censors shall make them known to me. The Censorate shall check its own members from receiving bribery. A Censor, who takes revenge on someone by impeachment, thus abusing his power shall be prosecuted. But he will not be blamed, even if what he says is not right. And what he says is right will be adopted. ${ }^{53}$

From the above, the duties and modus operandi of the censorate court and its officers have been exhaustively highlighted. It is important to note that the Emperor proscribe revenge by impeachment. Thus conflict of interest is not allowed on the part of the official of the court. Prevention of official neglect of duties is considered as one of the focal point in the terms of the Censorate court.

Professor Walker attempted to investigate why Western scholars have not learnt from the east or at least acknowledge the role of the Control Yuan in public administration. He further opined that this was due to language difficulty and the

\footnotetext{
${ }^{51}$ Richard L. Walker, "The Control System of the Chinese Government," The Journal of Asian Studies 7, no. 1 (1947): 3-21; Tao, "The Chinese Ombudsman and Control System"

${ }^{52}$ Charles O. Hucker, "The Traditional Chinese Censorate and the New Peking Regime," American Political Science Review 45, no. 4 (1951): 1041-57.

${ }^{53}$ Cited in, Tao, "The Chinese Ombudsman and Control System"
} 


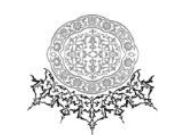

inept refusal of Western scholars in paying attention to the political practices in Chinese communities. ${ }^{54}$ Thus, this Ombudsman like institution was largely unknown to the world.

A closer look at the Ancient ombudsman in the Islamic era, India legal text and the Chinese civilization shows that they were all tools to check public maladministration, regulate market activities and upholding public morality. Proactiveness in the prevention and investigation of complaints are important underpinnings of the public maladministration mechanism in the ancient cultures. In addition, the officers were allowed certain degree of independence to take punitive measures against person found culpable.

\subsection{Scandinavian Ombudsman}

The Scandinavian region comprising of Sweden, Norway, Finland and Denmark have been credited with the origin and institutionalisation of modern Ombudsman. Although it is accurate to assert that contemporary ombudsman in its current form owes its name to Scandinavian ombudsman ${ }^{55}$ its form and substance is indebted to ancient ombudsman practices of the Ottoman.

In 1713, the King of Sweden appointed the Chancellor of Justice or the Justite Ombudsman (JO) to investigate royal officials and later the militie ombudsman who is commissioned for the military servicemen. ${ }^{56}$ In order to maintain its independence from the King and give the office a force of law, the ombudsman was established under the 1809 Swedish democratic constitution and the appointment was transferred to the parliament. In addition, the jurisdiction over complaints was enlarged to include 'observance of law and statute. ${ }^{57}$ According to Caiden, the Swedish Ombusman is the citizen's defender concerned with resolving citizen's complaint against judicial maladministration and public service. Until 1904, the military ombudsman and justice ombudsman were separate offices but the Riksdag i.e., Swedish parliament insisted that the Ombudsman be granted general powers over public administration. The impact was felt on civil right, prisons reform, police brutality, protection of free speech and press freedom. ${ }^{58}$

\footnotetext{
${ }^{54}$ Walker, "The Control System of the Chinese Government," 4.

${ }^{55}$ Lester B. Orfield, "The Scandinavian Ombudsman,” Administrative Law Review (1966): 774.

${ }^{56}$ Alfred Bexelius, "The Origin, Nature, and Functions of the Civil and Military Ombudsmen in Sweden," The Annals of the American Academy of Political and Social Science 377, no. 1 (1968): $10-19$.

${ }^{57}$ Caiden, MacDermot, and Sandler, The Institution of Ombudsman.

${ }^{58}$ Orfield, "The Scandinavian Ombudsman," 14.
} 


\section{상}

Alfred Bexelius, a former Judge and Ombudsman in Sweden between 1956 and 1968 succinctly state the position of the law with respect to breach of duties by government officials:

The law prescribes that if a judge or a civil servant, because of neglect, ignorance, or want of skill, disregards what is encumbent upon him by law, he shall be subject to fine or to suspension for such disregard of duty. On the basis of this rule a judge may be fined for delaying suits, a policeman for not being impartial when investigating a crime, and a civil servant can be held responsible if he acts in conflict with the nature of his service even if there no special instructions in regard thereto. This penal responsibility of public servants combined with the obligation to compensate for damage caused by error - has restrained them from unduly interfering with or neglecting the rights of citizens. This rule is the basis for the investigations and decisions of the ombudsmen. ${ }^{59}$

It must be noted that the Ombudsman also regulates behaviour of government officials in relation to citizens, a Swedish ombudsman as saying that "it is against Swedish law for an official to be stupid and arrogant. $" 60$

By 1919, developments in the practice of Swedish institutions such as Ombudsman for civil and citizens right had spread to its neighbour in Finland. Through the Constitution Act of 1919, the citizen protection against the arbitrariness of officialdom was strengthened. ${ }^{61}$ This was necessary to reform government institutions which have been ravaged by further 100 years of Russian tyrannical rule. $^{62}$ The conquer Finland in 1809 by the Russian emperor almost influenced the Ombudsman office in Finland. But the situation was salvaged through a successful revolt which granted the Finn freedom from Russia in 1919.

A common denominator in the development Scandinavian ombudsman is the need to protect civil right, public maladministration and defense of citizens against officialdom. In 1955, Denmark established the office of Ombudsman which was modelled after the Swedish system while Norway also followed few years after with focus on grievance against public maladministration. ${ }^{63}$

The Scandinavian Ombudsman which emerged in the 18th and 19th century has been considered by most western and non-western writers as the origin of modern Ombudsman. This is notwithstanding the existence of ancient forms of grievance mechanisms in the Islamic, Indian and Chinese tradition. However, an

${ }^{59}$ Alfred Bexelius, "The Swedish Ombudsman," The University of Toronto Law Journal 17, no. 1 (1967): 170.

${ }^{60}$ Marion K. Sanders, “Sweden's Remedy for Police Brutality," Harper's 229, no. 1374 (1964): 132-36.

${ }^{61}$ Donald C. Rowat, "Finland's Defenders of The Law: The Chancellor of Justice and the Parliamentary Ombudsman," Canadian Public Administration 4, no. 3 (1961): 316-25.

${ }^{62}$ Ibid., 317.

${ }^{63}$ Stephen Hurwitz, "Denmark's Ombudsmand: The Parliamentary Commissioner for Civil and Military Government Administration," Wisconsin Law Review (1961), 169. 


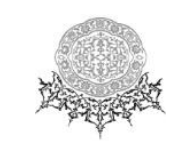

inquiry into the origin of Swedish ombudsman makes it seems that the institution evolves from the powers and creative administrative prowess of King Charles XII of Sweden. Later evidences have unearthed the verifiable origin and supplant the mystery surrounding the discourse. Could this be an intended sabotage of history and a denial of cross-cultural factors between competing civilizations? The section will attempt to address this question and the retrace the spread of Ombudsman in the Scandinavian.

\subsubsection{Scandinavian Ombudsman and its Islamic Origin}

In an attempt to unravel purpose behind the ombudsman idea, John Bainbridge quoted a former Swedish Ombudsman-Alfred Bexelius who mentioned that, "Nobody knows exactly how the institution of Ombudsman was conceived." 64 Bexelius added that "little is known in details about what was behind the creation of the office of $\mathrm{JO}$, or even with whom the proposal originated." ${ }^{65}$ According to Bexelius, it is not clear where the young King Charles XII of Sweden got the ombudsman idea.

The puzzle on the origin of the Ombudsman idea is attributable the Great Nordic War in Europe which led to the uneventful asylum sought by King Charles XII with friendly Ottoman Turks. During the exile, the king and his royal camp ruled his country from Ottoman territory Bender, where he spent five years under the protection of the ottoman Sultan. Similarly, King Charles was also able to request military assistance against the Russians at some times during his stay. ${ }^{66}$ It could be safe to conclude that the exile in the Ottoman Empire for a period of five years is sufficient enough for the king to imbibe some cross cultural learning and to observe the workings of the Muhtasib and other public machineries of the Ottoman Turks.

The fact of cultural learning between the Muslim Turks and King Charles in the development of the idea of Ombudsman was identified in the words of Roberta Jamieson. She opined that modern day ombudsman as a matter of fact is not an innovation from the West, whether in Sweden, America or Canada but a product of cultural learning and cross-cultural contacts between King Charles XII of Sweden and the Ottoman Turks. He said as follows:

Yet it is a fact, if we will acknowledge it, that the origins of the Swedish Ombudsman, our progenitor of record, came from the kind of cross-cultural contact I am advocating. In 1709, King Charles XII was forced by the Russians to seek refuge in Turkey where he found the Ottoman Turks with an institution known as "Qazi'ul' Quzat" or "judges of judges." Even

\footnotetext{
${ }^{64}$ John Bainbridge, “A Civilized Thing,” New Yorker Magazine (1965), 165.

${ }^{65}$ Alfred Bexelius, "The Ombudsman for Civil Affairs"; Rowat, The Ombudsman 22 (1965): 24. JO refers to Justite Ombudsman

${ }^{66}$ Frans Gunnar Bengtsson, The Life of Charles XII, King of Sweden, 1697-1718 (Macmillan, 1960); Francois Marie Arouet De Voltaire and Charles XII, The History of Charles XII, King of Sweden, 1801.
} 


\section{-}

before he left Turkey, Charles took moves that would lead to the creation of a similar office in Sweden mandated to obtain greater accountability of government administrators. ${ }^{67}$

Apparently, the encounter of the King during his rule from exile have made him to understand the modus operandi of Qadhi' ul Qudhāt or Judge of judges which was later transplanted as Justite Ombudsman (JO) in the Scandinavian countries. This explains the advent of ombudsman in the Scandinavian much earlier than the United States, Britain and Canada. As will be seen in the next section, modern trends have reclassified and expand the scope and practice of ombudsman.

\section{Classification of Ombudsman}

Ombuds practice and research has exceeded the bounds of parliamentary ombudsman also known as classical ombudsman which emerged in Sweden. Initially applied to redress public maladministration, it has been extended to other quasipublic, private and professional arrangement with the aim of providing confidential, impartial and mostly free mechanism for consumer protection, complaint handling and dispute resolution options. ${ }^{68}$

According to Rowat, ${ }^{69}$ the classification of ombudsman should be based on the extent to which they can be distinguished from the classical ombudsman system. He opined that there can only be two broad categories i.e., public sector and private sector. The novelty of the Swedish and Danish classical Ombudsman and their relevance to the parliament, municipalities, government and public services have been overshadowed with new trend of Ombuds programs in other commercial and business concerns. The phenomenon of private ombudsman enterprise ${ }^{70}$ has raised concerns over the role of private agencies in the administration of justice within the context of state powers. To this end, the UK Justice Department has described the current ombudsman arrangement as follows:

It would be wrong to take too narrow a view of what constitutes the state. For example, the privatisation of a range of public utilities led to the establishment by Parliament of a range of regulatory bodies that may properly be regarded as emanations of the state. There are other regulatory bodies that have been established in such fields as charities, financial services or gambling to which the same applies. Furthermore, as more of central and local government business is privatised or contracted out to private agencies, a wider view must be taken of what constitutes administrative justice. ${ }^{71}$

\footnotetext{
${ }^{67}$ Roberta Jamieson, "The Ombudsman: Learning from Other Cultures," Ottawa Law. Review
} 25 (1993): 629.

${ }^{68}$ Donald Cameron Rowat, A Worldwide Survey of Ombudsmen (International Ombudsman Institute, 1997), 1.

${ }^{69}$ Ibid.

${ }^{70}$ Trevor Buck, Richard Kirkham, and Brian Thompson, The Ombudsman Enterprise and Administrative Justice. (Ashgate, 2010), 4.

71،"The Developing Administrative Justice Landscape,” para. 14, accessed March 9, 2016, http://ajtc.justice.gov.uk/docs/landscape_paper.pdf. 


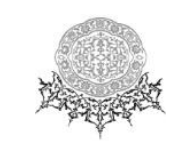

A contributory factor to the upsurge in non-classical Ombuds program is the privatization of public services and appeal towards Public Private Partnership (PPP) arrangement which has continued unabated in various hitherto public services. ${ }^{72}$ When public services go into private hands, it seems appropriate that the complaint emanating from such private services must be initially addressed through internal mechanisms. Consequently, it seems impossible for the government to continue to operate free consumer protection mechanism for an industry which might be outside its control. Private ombudsmen thus began to gain relevance in the entire privately held sector with some level of co-regulation and self-regulation models. ${ }^{73}$ From the foregoing, this article identifies the existence of the following:

i. Classical/Traditional Ombudsman

This form of ombudsman mirrors the Swedish Ombudsman with respect to its objective of addressing problems within the general public domain. It is 'generalist' in scope and can be understood from the context of addressing 'actions or policies of government entities or its representatives. ${ }^{74}$ In some countries, the classical ombudsman has been used to combat corruption and public maladministration.

ii. Legislative or Parliamentary Ombudsman

Closely related to the classical ombudsman is the Legislative or parliamentary ombudsman which is also known as parliamentary commissioner in other some jurisdictions. It is responsible for addressing the concerns of the public over internal issues regarding accountability of individuals and government entities. The difference between Classical and parliamentary ombudsman is not significant as both are appointed by either the executive or legislature and subject to legislative confirmation. It is important to state that the Parliamentary ombudsman is responsible to and regarded as a part of the legislature.

\section{iii. Executive Ombudsman}

An executive ombudsman can perform Ombuds function in both private and public sector. This is unlike the classical and legislative ombudsman is restricted only to public concerns and complaint with respect to failures of public entities, contractors and agencies. Executive Ombuds is appointed by the chief executive from whom he derives his powers and assistance to obtain

\footnotetext{
${ }^{72}$ Margot Priest, "The Privatization of Regulation: Five Models of Self-Regulation," Ottawa L. Rev. 29 (1997): 233.

${ }^{73}$ Ibid; Anthony Ogus, "Rethinking Self-Regulation," Oxford Journal of Legal Studies 15, no. 1 (1995): 97-108; Neil Gunningham and Joseph Rees, "Industry Self-regulation: An Institutional Perspective," Law and Policy 19, no. 4 (1997): 363-414.

${ }^{74}$ Thacker, "Good Intentions Gone Astray: How the ABA Standards Affect Ombudsmen"
} 


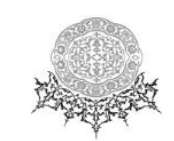

redress. $^{75}$ There is no legislative involvement in the appointment and operation of executive Ombuds thus making it less cumbersome and limited in scope and jurisdiction. In other words, the jurisdiction of this form of ombuds is usually limited to specific subject matter or serves as complaint officer within public agencies such as or private establishment such as Local government, prisons, patient care and mental institutions, prisons.

iv. Organizational Ombudsman

The most acceptable explanation of organizational or corporate ombudsman is given by the International Ombudsman Association (IOA). It give a simplified definition as a designated neutral who is appointed or employed by an organization to facilitate the informal resolution of concerns of employees, managers, students and, sometimes, external clients of the organization."76 The need for employees to have an exclusive grievance handling system which is capable of withstanding the strict hierarchy of an organization has been said to be one of the impetus for Organizational Ombudsman within a workplace setting. ${ }^{77}$ Although the ombudsman can work in both private and public sector, the fear of retribution from higher level employee can affect the complaint handling process.

\section{Relevance of Ombudsman in Business Regulation}

Market regulation in its elementary form seeks to regulate business environment by ensuring confidence, trust among market players. It is important to know how the early market place was organised within the context of early ombudsman practice and in the absence of robust laws to enhance competitions, consumer protection, price control and enforcement of market rules. The basic objectives of modern market regulation have undoubted taken some clue from early business practices and built upon by existing systems.

This section analyses the role of ombudsman in commercial and business regulation as practiced in ancient cultures. It has been noted that different cultures in history have practised Ombudsman or its ilk at different period. Similarly, there has not been uniformity in the modus operandi and adaptation of ombudsman to different field of trades. In addition, there are varying degrees of ombudsman in commercial activities around the world. This discussion will compare the market regulation function in different civilizations mentioned above.

\footnotetext{
${ }^{75}$ Alan J. Wyner, "Executive Ombudsmen, and Criticisms of Contemporary American Public Bureaucracy," Executive Ombudsmen in the United States, Edited by Alan J. Wyner, (1973), 10-11.

76،"The International Ombudsman Association - Frequently Asked Questions," accessed March 15, 2016, https://www.ombudsassociation.org/Resources/Frequently-Asked-Questions/Whatis-an-Organizational-Ombudsman.aspx.

${ }^{77}$ Rowat, A Worldwide Survey of Ombudsmen, 5.
} 


\section{상}

This article alludes to the fact that not all early ombudsman practices focussed on market regulation. The institution and office of Muhtasib which existed during the early Islamic history was an essential part of commercial markets in Makkah and Madinah. Similarly, almost every market has an appointed officer known as Amil 'ala suq charged with market function. This institution which is peculiar with market regulation only has not thrived in the Scandinavia.

Scale and measures which was an essential part of the market regulation during the times of Prophet Muhammad $(S A W)$ till the Ottoman era, was not covered. This is because the Scandinavian Ombudsman major focused on public administration which was largely influenced by civil right and public service administration. The nature of Ombudsman in the Scandinavian did not envisage its use in market control but only for the maintenance of law and order.

The Muhtasib, Agoranomos and its Indian similitude possess unique features such as, proactiveness rather than "wait and see" approach. On the other hand, modern Ombuds offices wait for complainants or disputants to submit complaints. This was not the case in ancient Ombuds practice which is largely based on religious and societal standards. Another distinction can be seen in the categorisation of ombudsman largely into public and private between sector practitioners. This perhaps explain the fact that the Ombudsman system handed down to the NorthAmerican, Africa and Asia in the late twentieth century mainly focussed on human right, upholding civil liberties and resolution of grievance against public mal administration. $^{.8}$

\section{Conclusion}

An in-depth look at ombudsman across cultures shows that there is limited scope for ombudsman in the market place or business regulation. However, under the Islamic tradition which appoints a muhtasib to monitor the market has the power to perform the following specific roles:

i. Price ceiling (narkh) and Permissible price-fixing (tas'ir)

ii. Inspect and ensure standard weights, scales and measures

iii. Prevention of unlawful sales transaction between vendors and purchasers

iv. Uphold the right of the purchaser i.e., right of repayment, right of option (khiyar) and right or workers to wages

v. Regulation of trade and profession

From the foregoing, this paper concludes the institution of Muhtasib or Islamic ombudsman is more adaptable to business regulation. Ancient forms of Ombudsman and the characteristic of modern ombudsman show some convergences and differences. From the ancient practices to the more recent Scandinavian

\footnotetext{
${ }^{78}$ Rowat, $A$ Worldwide Survey of Ombudsmen
} 


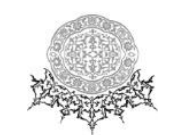

Ombudsman, market regulation thrives in some part of the world than others. The discussion reveals that the concept has continued to develop human right and public complaint but with limited scope. Muhtasib is distinct due to its investigative powers in dispute avoidance, dispute resolution, complaint management and other ADR mechanisms. The discussion on the relevance of ombudsman for business is intended to lay the foundation for increased use of ombudsman as a regulatory tool in the business regulation.

\section{Bibliography}

Bainbridge, John. "A Civilized Thing." New Yorker Magazine, Accessed February 13, $1965<$ https://www.newyorker.com/magazine/1965/02/13/a-civilized-thingto-do>.

Bengtsson, Frans Gunnar. The Life of Charles XII, King of Sweden, 1697-1718. Sweden: Macmillan and Company, 1960.

Bexelius, Alfred. "The Ombudsman for Civil Affairs." edited by Donald C. Rowat. The Ombudsman 22 (1965)

—. "The Origin, Nature, and Functions of the Civil and Military Ombudsmen in Sweden." The Annals of the American Academy of Political and Social Science 377, no. 1 (1968): 10-19.

- "The Swedish Ombudsman." The University of Toronto Law Journal 17, no. 1 (1967): 170-76.

Bhatt, Justice J. N. “Ombudsman: An Effective ADR.” All India Reporter 88 (2001)

Boeckh, August. Corpus Inscriptionum Graecarum. Vol. 1. Berlin: Reimer, 1843.

Buck, Trevor, Richard Kirkham, and Brian Thompson. The Ombudsman Enterprise and Administrative Justice. Ashgate, 2010.

Buckley, R. P. “The Muhtasib.” Arabica 39 (1992): 59-117.

Caiden, Gerald E., Niall MacDermot, and Ake Sandler. The Institution of Ombudsman. International Handbook of the Ombudsman: Evolution and Present Function. Vol. 1. Westport, CT: Greenwood Press, 1983.

Chernick, Richard. "ADR' Comes of Age: What Can We Expect in the Future?" Pepperdine Dispute Resolution Law Journal 4, no. 2 (2012).

De Voltaire, Francois Marie Arouet, and Charles XII. The History of Charles XII, King of Sweden, 1801.

Foster, Benjamin R. "Agoranomos and Muhtasib." Journal of the Economic and Social History of the Orient/Journal de L'histoire Economique et Sociale de l'Orient, 1970, 128-44.

Frank, Bernard. "The Ombudsman-Revisited." International Bar Journal 6 (1975)

Gadlin, H., and E. Pino. "Neutrality: What an Organizational Ombudsperson Might 


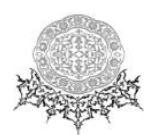

Want to Know." Dallas: The Ombudsman Association,1997.

R. L. G. "Gendered Language: An Ombudsman by Any Other Name Would Still Field Complaints.The Economist." April 23, 2013 Accessed March 1, 2016. $<$ http://www.economist.com/blogs/johnson/2013/04/gendered-language $>$.

Glick, Thomas F. 'Muhtasib' and 'Mustasaf': A Case Study of Institutional Diffusion." Viator 2 (1971)

Gran, Brian, and Dawn Aliberti. "The Office of the Children's Ombudsperson: Children's Rights and Social-Policy Innovation." International Journal of the Sociology of Law 31, no. 2 (2003): 89-106.

Griffin, Tim. "The Evolution of the Role of Ombudsperson on University and College Campuses." The Fourth $R$ (the Newsletter of the National Association for Mediation in Education) 55 (1995).

Gunningham, Neil, and Joseph Rees. "Industry Self-Regulation: An Institutional Perspective." Law and Policy 19, no. 4 (1997): 363-414.

Hazm, Ibn, and Abu Muhammad'Alli. 'Jamharat Ansāb al-'Arab. Edited byAbd AlSalām Hārūn. Cairo, 1962.

Hill, Larry B. "The Institutionalization, the Ombudsman, and Bureaucracy." American Political Science Review 68, no. 3 (1974): 1075-85.

Hoffmann, Florian, and Frédéric Mégret. "Fostering Human Rights Accountability: An Ombudsperson for the United Nations?" Global Governance: A Review of Multilateralism and International Organizations 11, no. 1 (2005): 43-63.

Hucker, Charles O. "The Traditional Chinese Censorate and the New Peking Regime.” American Political Science Review 45, no. 4 (1951): 1041-57.

Hurwitz, Stephen. "Denmark's Ombudsmand: The Parliamentary Commissioner for Civil and Military Government Administration." Wisconsin. Law Review 1961,

James, Rhoda. Private Ombudsmen and Public Law. Ashgate, Dartmouth, 1997.

Jamieson, Roberta. "The Ombudsman: Learning from Other Cultures." Ottawa Law. Review 25 (1993)

Kern, Karen. Muhammad Khalid Masud, Rudolph Peters, and David S Powers. Dispensing Justice in Islam: Qadis and their Judgments. Leiden: Brilll, 2010.

Magie, David. Roman Rule in Asia Minor. Vol. 6. Princeton, 1950.

McMillan, John. "What's in a Name? Use of the Term 'Ombudsman." Presentation, Commonwealth Ombudsman to the Australian and New Zealand Ombudsman Association, 2008.

Muhammad Al-Mawardi. Al-Ahkam al-Sultaniyyah. Cairo: Al Halabi Press, 1960.

Ogus, Anthony. "Rethinking Self-Regulation." Oxford Journal of Legal Studies 15, no. 1 (1995): 97-108. 
Orfield, Lester B. "The Scandinavian Ombudsman." Administrative Law Review, (1966), 7-74.

Priest, Margot. "The Privatization of Regulation: Five Models of Self-Regulation." Ottawa Law. Review 29 (1997): 233.

Rahmani, Ziaullah. "Wafaqi Mohtasib (Federal Ombudsman) Institution: An Effort of Harmonization with Shari 'ah." Annual Report of the Wafaqi Mohtasib for 1985.

Raschke, M. G. "The Office of Agoranomos in Ptolemaic and Roman Egypt." Akten Des 13. Internationalen Papyrologenkongresses (1974): 349-56.

Rebstock, Ulrich. "Weights and Measures in Islam." In Encyclopaedia of the History of Science, Technology, and Medicine in Non-Westen Cultures. edited by Helaine Selin, 2255-67. Netherland: Springer Science and Business Media, 2008.

Reif, Linda C. The International Ombudsman Anthology: Selected Writings from the International Ombudsman Institute. Martinus Nijhoff Publishers, 1999.

Rowat, Donald C. "Finland's Defenders of The Law: The Chancellor of Justice and the Parliamentary Ombudsman." Canadian Public Administration 4, no. 3 (1961): 316-25.

—. "The New Private-Sector Ombudsmen." Policy Options 24, no. 10 (2003): 46-48.

Rowat, Donald Cameron. A Worldwide Survey of Ombudsmen. International Ombudsman Institute, 1997.

Sanders, Marion K. “Sweden's Remedy for Police Brutality." Harper's 229, no. 1374 (1964): 132-36.

Shahabuddin, Abu Saim Md. "Regulation of Economic Life in Hisbah Literature." International Islamic University Malaysia, 2009.

Shin, Joon. "Legal Studies, and Honors Thesis-Discussion on the Models of ADR," (2011): 1-29.

Sperber, Daniel. "On the Office of the Agoranomos in Roman Palestine." Zeitschrift Der Deutschen Morgenländischen Gesellschaft 127, no. 2 (1977): 227-43.

Sternlight, Jean R. "Is Binding Arbitration a Form of ADR ?: An Argument That the Term 'ADR' Has Begun to Outlive Its Usefulness" (2013).

Tao, Pai-Chuan. "The Chinese Ombudsman and Control System." St. John's Law. Review. 41 (1966)

Thacker, Sara. "Good Intentions Gone Astray: How the ABA Standards Affect Ombudsmen." Journal of the International Ombudsman Association 2, no. 1 (2009).

“The Developing Administrative Justice Landscape." Accessed March 9, 2016. 
$<$ http://ajtc.justice.gov.uk/docs/landscape_paper.pdf $>$.

"The International Ombudsman Association-Frequently Asked Questions." Accessed March 15, 2016. <https://www.ombudsassociation.org/Resources/FrequentlyAsked-Questions/What-is-an-Organizational-Ombudsman.aspx>.

"The Ombudsman Association-Standards of Practice." Accessed March 16, 2016. $<$ http://web.mit.edu/negotiation/toa/TOAsop.html $>$.

Vernia, Pedro. "The Muhtasib of Valencia and Pharmacy in Aragon." Pharmacy in History 30, no. 2 (1988): 89-93.

Walker, Richard L. "The Control System of the Chinese Government." The Journal of Asian Studies 7, no. 1 (1947): 3-21.

Wiegand, Shirley A. "A Just and Lasting Peace: Supplanting Mediation with the Ombuds Model." Ohio St. J. on Disp. Resol. 12 (1996): 95.

Willis, Grant L. "Security Council Targeted Sanctions, Due Process and the 1267 Ombudsperson." Geo. J. Int'l L. 42 (2010): 673.

Wyner, Alan J. "Executive Ombudsmen, and Criticisms of Contemporary American Public Bureaucracy." Executive Ombudsmen in the United States. Edited by Alan J. Wyner, 1973, 3-15.

Yaacob, Ahmad Che, and Normah Omar. "Fraudulent Business Practices in Early Islam as Reported in a Classical Text." Malaysian Accounting Review 13, no. 1 (2014): 129-42. 